\title{
Performance of soybean in hydromorphic and nonhydromorphic soil under irrigated or rainfed conditions
}

\author{
Thiago Schmitz Marques da Rocha(1), Nereu Augusto Streck(1), Alencar Junior Zanon(2), Elio Marcolin ${ }^{(2)}$, \\ Mirta Teresinha Petry ${ }^{(1)}$, Eduardo Lago Tagliapietra ${ }^{(1)}$, Darlan Barlest ${ }^{(1)}$ and Kelin Pribs Bexaira ${ }^{(1)}$
}

(1)Universidade Federal de Santa Maria, Avenida Roraima, no 1.000, Cidade Universitária, Prédio 77, Sala 2, Camobi, CEP $97105-900$ Santa
Maria, RS, Brazil. E-mail: thiagosmr@msn.com, nstreck2@yahoo.com.br, mirta.petry@gmail.com, eduardotagliapietra@hotmail.com,
darlanbalest@gmail.com, kelin_bexaira@hotmail.com ${ }^{(2) I n s t i t u t o ~ R i o ~ G r a n d e n s e ~ d o ~ A r r o z, ~ A v e n i d a ~ M i s s o ̃ e s, ~ n o ~ 342, ~ S a ̃ o ~ G e r a l d o, ~}$
CEP 90230-100 Porto Alegre, RS, Brazil. E-mail: alencarzanon@hotmail.com, elio-marcolin@hotmail.com

Abstract-The objective of this work was to evaluate soybean cultivation in a hydromorphic or nonhydromorphic soil, with or without supplemental irrigation. Field experiments were carried out with the TECIRGA 6070RR and A 6411RG cultivars in highlands (nonhydromorphic soils) and lowlands (hydromorphic soils), which are traditionally cultivated with irrigated rice. The following parameters were determined in both soybean cultivars: leaf area index, developmental stages, dry matter partition, and leaf gas exchange. Low water stresses, which commonly occur either by deficit or excess in soybean areas cultivated in hydromorphic soils, do not affect the development and partitioning of dry matter; however, they cause reductions in stomatal conductance, photosynthetic rate, and leaf area evolution. Growing soybean in lowlands exposes plants to water stress, even in years with well-distributed rainfall during the growing season, due to the low water storage capacity of these soils.

Index terms: Glycine max, gas exchange, irrigation, lowlands.

\section{Desempenho da soja cultivada em solo hidromórfico e não hidromórfico com ou sem irrigação}

\begin{abstract}
Resumo - O objetivo deste trabalho foi avaliar o cultivo de soja em solo hidromórfico ou não hidromórfico, com ou sem irrigação suplementar. Experimentos em campo com as cultivares TECIRGA 6070RR e A 6411RG foram realizados em terras altas (solos não hidromórficos) e em terras baixas (solos hidromórficos), que são tradicionalmente cultivadas com arroz irrigado. Determinaram-se, nas duas cultivares de soja, os seguintes parâmetros: índice de área foliar, estágios de desenvolvimento, partição de matéria seca e quantificação das trocas gasosas em nível foliar. Pequenos estresses hídricos, que comumente ocorrem por deficit ou excesso em áreas de soja cultivada em solo hidromórfico, não influenciam o desenvolvimento e a partição de matéria seca; porém, provocam reduções da condutância estomática, da taxa fotossintética e da evolução da área foliar. O cultivo de soja em solos hidromórficos faz com que as plantas sejam expostas ao estresse hídrico, até mesmo em anos com precipitação de chuvas bem distribuída ao longo da estação de crescimento, em razão da baixa capacidade de armazenamento de água desses solos.
\end{abstract}

Termos para indexação: Glycine max, trocas gasosas, irrigação, terras baixas.

\section{Introduction}

One of the first attempts to grow soybean [Glycine $\max$ (L.) Merr.] on hydromorphic soils in Southern Brazil began in the mid-twentieth century (Bernardes, 1946). However, only in the last decade there has been an expressive expansion of areas under soybean in the southern half of Rio Grande do Sul state, which have been traditionally used for irrigated rice as a monoculture, and for extensive livestock farming (Vernetti Junior et al., 2009). The soybean area cultivated in rotation with irrigated rice in Rio Grande do Sul increased and consolidated in nearly 280 thousand hectares, due to the improvement of management practices, and the development of tolerant cultivars to soil water excess (Zanon et al., 2015; Irga, 2016).

Soils traditionally grown with soybean in Brazilian highlands are of a good natural drainage, that is, they are nonhydromorphic soils (Miyasaka \& Medina, 1981). In addition, soils cultivated with irrigated rice in Rio Grande do Sul are predominantly Planosols, 
Gleysols, and the association between them (Thomas \& Lange, 2014); they are characterized by being hydromorphic soils with poor natural drainage, due to the flat low lands, soil profile with shallow surface layer, and almost impermeable subsurface layer (Streck et al., 2008).

Conventional tillage with successive plowing and harrowing causes these lowland soils to show great physical limitations, such as aggregate disintegration and reduced macroporosity (Sartori et al., 2016). Therefore, when growing soybean in these areas, water excess and deficit may be more frequent than in nonhydromorphic soils (Thomas \& Lange, 2014; Sartori et al., 2016). These water stress periods can result in metabolic changes that directly affect the plant energy balance, and cause a reduction of potential crop productivity (Cornelious et al., 2006).

Knowing genotype response to water stress deficit, or excess - is important for cultivar selection and recommendation, besides determining welladapted techniques to grow soybean in hydromorphic soils, with the aim to express productivity potential (Thomas \& Lange, 2014). If, on the one hand, rotating soybean crops with irrigated rice have increased recently, on the other hand, there are few studies on the development and productivity of the used soybean cultivars in hydromorphic soils in Brazil (Zanon et al., 2015, 2016; Sartori et al., 2016), Uruguay (Chebataroff et al., 2002; Castillo et al., 2013), and Argentina (Caride et al., 2011). These few studies do not completely explain the differences of the ecophysiological processes (photosynthetic rate, dry matter partition), and the development of soybean cultivated in hydromorphic and nonhydromorphic soils in an integrated way. This approach may help soybean breeding programs to develop cultivars for cultivation in hydromorphic soils, and to improve management practices to reduce water stress in soybean cultivars currently used in rotation with irrigated rice, in order to assist extensionists, consultants, and farmers in decision-making.

The objective of this work was to evaluate soybean crop in a hydromorphic or nonhydromorphic soil, with or without supplemental irrigation.

\section{Materials and Methods}

Field experiments were carried out with soybean during the 2014/2015 growing season, in Cachoeirinha
( $29^{\circ} 56^{\prime} \mathrm{S}, 51^{\circ} 07^{\prime} \mathrm{W}$, at $10 \mathrm{~m}$ altitude), and in Santa Maria $\left(29^{\circ} 43^{\prime} \mathrm{S}, 53^{\circ} 43^{\prime} \mathrm{W}\right.$, at $95 \mathrm{~m}$ altitude), both in the state of Rio Grande do Sul, Brazil. The soil in Cachoeirinha is a Gleissolo Háplico Ta distrófico típico (Streck et al., 2008) - Typic Albaqualf, which represents the hydromorphic soils cultivated with irrigated rice in Southern Brazil. In Santa Maria, the soil is an Argissolo Vermelho distrófico arênico (Streck et al., 2008) Typic Hapludalf, with 7\% slope and good drainage conditions, which represents the conditions of soybean crops in nonhydromorphic soils in Rio Grande do Sul. Undisturbed samples were collected before sowing, to determine the soil physical characteristics (bulk density, macro- and microporosity, and compacted layer), and to define the homogeneous layers in each profile. In the two sites, climate is a Cfa-subtropical humid with hot summers - according to the classification of KöppenGeiger, with an undefined dry season.

Crop management practices included base fertilization, inoculation of Bradyrhizobium japonicum strains in seed, seed treatment with fungicide and insecticide, and control of weeds, pests, and diseases. Soybean cultivars used were TECIRGA 6070RR and A 6411RG of relative maturity groups (RMG) of 6.3 and 6.4, which show indeterminate and determinate growth types, respectively. These cultivars were selected because they show similar RMGs, they are widely cultivated in the state of Rio Grande do Sul for having different growth types and, mainly, because 'TECIRGA 6070RR' has a higher tolerance to soil water excess, in comparison to other commercial cultivars (Lange et al., 2013). Sowing was performed at $0.05 \mathrm{~m}$ depth on $10 / 24 / 2014$, with an experimental sowing machine, at $0.5 \mathrm{~m}$ spacing between rows, and density of 30 plants $\mathrm{m}^{-2}$, in both sites.

In Cachoeirinha, a randomized complete block experimental design was carried out with three replicates, in a split-plot, two-factorial design, in which the main plot consisted of the cultivars, and the subplots of water availability, that is, with or without supplementary irrigation. The experimental unit consisted of 26 plant rows with $10 \mathrm{~m}$ long, and irrigation was done by furrows. This experimental arrangement was used to better represent irrigation conditions and methods of soybean cultivation in rotation with irrigated rice, in the hydromorphic soils in Rio Grande do Sul. Soil water content was monitored by water balance calculation up to flowering. From this period 
on, the subsurface water potential was monitored with porous capsule tensiometers at $10 \mathrm{~cm}$ depth. Four irrigations were carried out during the development cycle when water potential reached $-40 \mathrm{kPa}$. In addition, 30 and $27 \mathrm{~mm}$ of water were applied at the R1 stage on 12/9/2014 and 12/19/2014, respectively; $30 \mathrm{~mm}$ at R3, on $1 / 7 / 2015$; and $15 \mathrm{~mm}$ at R5, on $2 / 6 / 2015$. Water depth in each plot was measured with a hydrometer and applied until irrigation furrows were filled with water.

In Santa Maria, a randomized complete block design was used, with five replicates, in a splitplot, two-factorial arrangement. Water availability consisted of the main plots (with or without supplementary irrigation), and the soybean cultivars' TECIRGA 6070RR and A 6411RG, the subplots. The experimental unit consisted of four plant rows with $3 \mathrm{~m}$ length. Irrigation was performed by a drip system, based on the calculation of the soil water balance, and the water depth applied was measured with a hydrometer to maintain the available water capacity (AWC) between $60-100 \%$, considering that the root system depth varies throughout the growing season. Eight irrigation events were provided, applying the following water depths: $35 \mathrm{~mm}$ at $\mathrm{V} 3$, on $11 / 15 / 2014$; $17 \mathrm{~mm}$ at $\mathrm{V} 4$, on 11/19/2014; $22 \mathrm{~mm}$ at V6, on 11/28/2014; $11 \mathrm{~mm}$ at R4, on $2 / 4 / 2015 ; 19,16$, and $24 \mathrm{~mm}$ at R5, on $2 / 6 / 2015,2 / 9 / 2015$, and $2 / 19 / 2015$, respectively; and $10 \mathrm{~mm}$ at $\mathrm{R} 6$, on $3 / 8 / 2015$.

Meteorological data were obtained from an automatic weather station located about $200 \mathrm{~m}$ from the experiments. The water balance model of Thornthwaite \& Mather (1955) was applied to calculate daily soil water balance. The Penman-Monteith approach was used (Allen et al., 1998) for the estimation of potential evapotranspiration $\left(\mathrm{ET}_{0}\right)$. The crop coefficient $(\mathrm{Kc})$ along the soybean development cycle were calculated by linear interpolation between the values reported by Berlato et al. (1986). For the V3, V10, and R5 stages, trenches of $80 \mathrm{~cm}$ in length by $50 \mathrm{~cm}$ depth were opened in the borders of each plot, and 10 plants were evaluated to follow the root system deepening and the layer with the highest concentration of roots.

Plant emergence date was considered when $50 \%$ of plants had cotyledons above the ground. Following the appearance of the first pair of unifoliate leaves, five plants located in the central row of each plot were marked with colored wires, which were evaluated every two days to identify the stages R1, R5, R6, R7, and R8, according to the scale by Fehr et al. (1971). The leaf area was also measured in these plants on a biweekly nondestructive basis, according to the methodology described by Richter et al. (2014). In all evaluations, the presence or absence of flowers and pods in the plant grain filling stage was determined, in order to analyze the period of total duration of flowering and grain filling.

Gas exchange measurements, such as stomatal conductance $\left(\mathrm{mol} \mathrm{H} \mathrm{H}_{2} \mathrm{O} \mathrm{m}^{-2} \mathrm{~s}^{-1}\right.$ ), photosynthetic rate $\left(\mu \mathrm{mol} \mathrm{CO} \mathrm{C}_{2} \mathrm{~m}^{-2} \mathrm{~s}^{-1}\right)$, photosynthetically active radiation $\left(\mu \mathrm{mol} \mathrm{m}{ }^{-2} \mathrm{~s}^{-1}\right)(\mathrm{PAR})$, and leaf temperature $(\mathrm{Tl})\left({ }^{\circ} \mathrm{C}\right)$ were measured in two plants marked in each plot with a gas exchange meter (LCi-SD Portable Photosynthesis System). Gas exchange measurements were performed between 11:00 and 13:00 $\mathrm{h}$ in clear days, at different times of the cycle, on the last leaf with a fully expanded trefoil on the main stem. As gas exchange evaluations are highly dependent on the soil water availability and plant water status, the analysis of variance was performed upon evaluation, considering the cultivar as factor A, and the daily soil water balance status without stress, due to soil water deficit $(\mathrm{ETc}=\mathrm{ETR})$, as factor B. The same analysis was performed under the condition of water defcit (Def.), when ETR $>$ ETc.

In Cachoeirinha, plants were collected from a $2 \mathrm{~m}$ row throughout the development cycle for dry matter; they were cut close to the soil level, separated into leaf blades, petioles, stems, pods, and grains, and ovendried at $60^{\circ} \mathrm{C}$, to determine the dry matter partition. Grain yield $\left(\mathrm{kg} \mathrm{ha}^{-1}\right)$ was calculated from two $2 \mathrm{~m}$ rows at plot centers. The analysis of variance was performed according to the split-plot two-factorial model, to test the significance of the factors and the interaction between cultivars and water availability. Analyses were performed with Sisvar, version 5.3 (Universidade Federal de Lavras, Lavras, MG, Brazil).

\section{Results and Discussion}

Abundant and well-distributed rainfall occurred during the 2014/2015 growing season in Rio Grande do Sul state, in both experimental sites. This fact contributed to an outstanding production and productivity in the state. Consequently, days with water deficiency in the municipality of Santa Maria were rare and, when they occurred, the deficiency showed 
low intensity. In the municipality of Cachoeirinha, the period of water deficiency was also not long and accentuated; however, short periods without rainfall (five to seven days) caused water deficiency (Figure 1), due to the low available water capacity (AWC) of the soil.

In Cachoeirinha, the root-blocking layer is around $13 \mathrm{~cm}$ depth, which is typical of paddy rice fields (Sartori et al., 2015, 2016). In Santa Maria, most of the root system was located up to $30 \mathrm{~cm}$ depth. The lower macroporosity in Cachoeirinha (Table 1) allows of low AWC and high density - which characterizes the loss of physical structure in hydromorphic soils, where irrigated rice is cultivated in Rio Grande do
Sul (Mentges et al., 2013) -, as well as permits the increasing of resistance to root penetration in the soil (Ortigara et al., 2014).

At both experimental sites, the developmental phases and the total cycle of soybean had a similar duration that was not affected by irrigation (Figure 2). These results agree with the results by Zanon et al. (2015), who found no differences in the duration of the developmental phases and the total development cycle of soybean cultivars grown in hydromorphic and nonhydromorphic soils, under no severe water stresses (deficiency or excess) during the development cycle. The main difference for development between the cultivars was the flowering period duration, which was
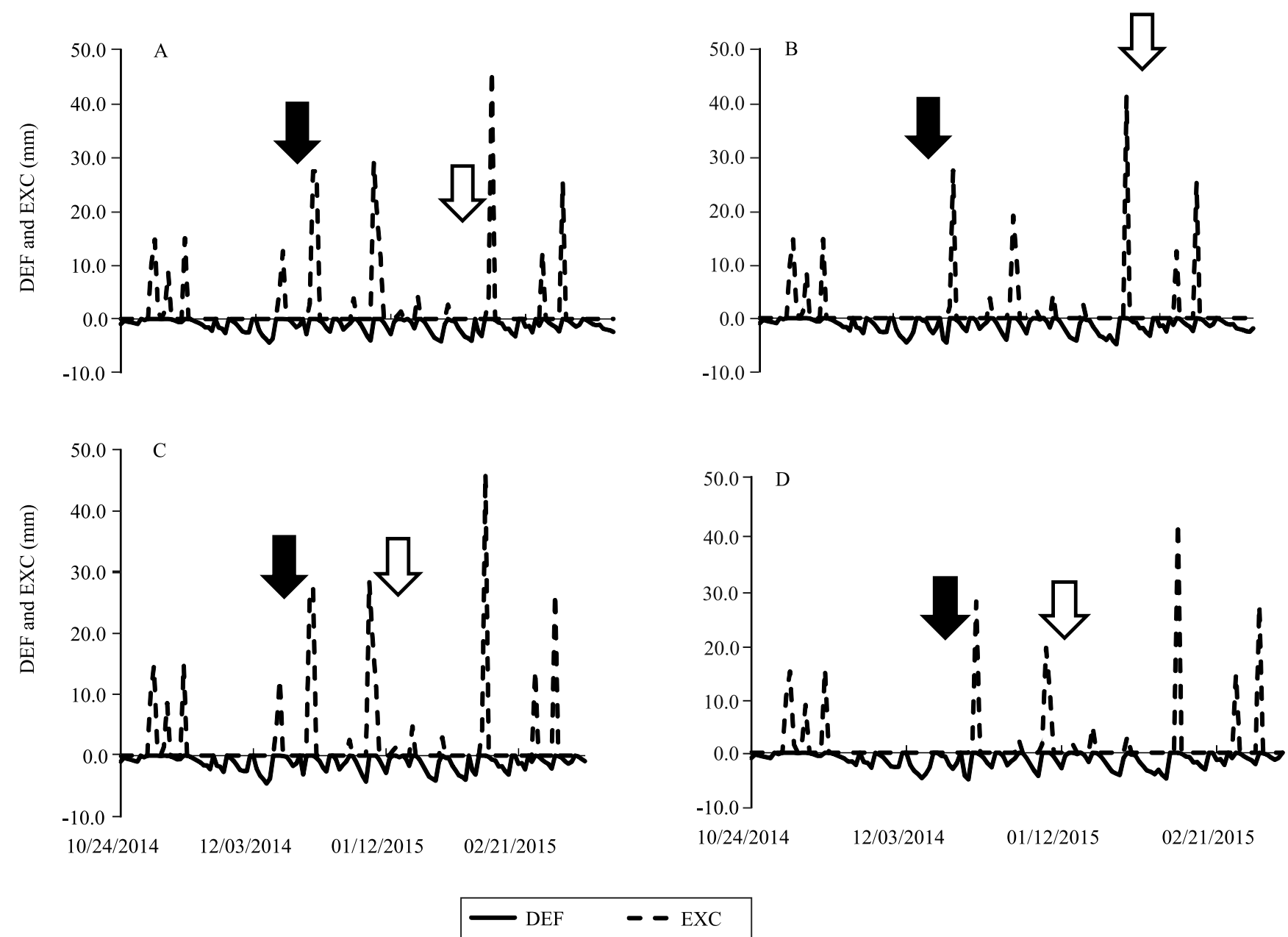

Figure 1. Daily soil water deficit (DEF) e surplus (EXC) throughout the experimental period for soybean (Glycine max) cultivars TECIRGA 6070RR (A and B) and A 6411RG (C and D) grown under irrigated (A and C) or nonirrigated (B and D) conditions, in the municipality of Cachoeirinha, in the state of Rio Grande do Sul, Brazil. Arrows indicate the date of the R1 (solid arrow) and R5 (open arrow) soybean developmental stages. 
$40 \%$ higher for TECIRGA 6070RR, and is associated with the indeterminate growth habit of this cultivar (Figure 2).

The maximum leaf area index (LAI) showed no interaction between cultivar and irrigation in the two evaluated sites. There were no differences for LAI between irrigated and nonirrigated treatments (Figure 3).

Management practices should be intensified in soybean cultivation in hydromorphic soils, in order to minimize stresses such as the loss of cellular turgor (first effect of water stress), which causes reduction of leaf growth rate (Streck, 2004) and, consequently, loss of soybean yield potential (Zanon et al., 2016).

The photosynthetic rates observed in Santa Maria (Table 2), close to $20 \mu \mathrm{mol} \mathrm{CO}_{2} \mathrm{~m}^{-2} \mathrm{~s}^{-1}$, are similar to those reported in the literature for sites without water stress (Sinclair, 1980; De Bruin et al., 2010). The lower values measured in Cachoeirinha, however, are close to $15 \mu \mathrm{mol} \mathrm{CO} \mathrm{CO}^{-2} \mathrm{~s}^{-1}$, and are similar to those reported as moderate water stress in soybean crops (Pereira, 2002). In Santa Maria, no stress altered the photosynthetic rate and stomatal conductance (Table 2). In Cachoeirinha, the evaluations under water deficiency conditions differed from those without stress, indicating that irrigation in Santa Maria was efficient and caused neither stomatal conductance (gs) nor photosynthetic rate (A) reduction. It also indicates that some response mechanisms to soil water stress were activated in Cachoeirinha (Streck, 2004).

In general, the lower values of photosynthetic rate and stomatal conductance in Cachoeirinha indicate that plants are more vulnerable to soil water stress in a hydromorphic environment (Thomas \& Lange,
2014), even in a year with regular and well distributed rainfall.

The differences observed in the water stress levels in Cachoeirinha caused no change on dry matter (DM) partitioning. Among cultivars, TECIRGA 6070RR grain weight showed an abrupt evolution for grain filling at the end of the cycle (Figure $4 \mathrm{~A}$ ), while A 6411RG showed a constant evolution for grain partition (Figure $4 \mathrm{~B}$ ). Leaf fraction, especially that of stem, had an inverse response to grain filling in both cultivars, indicating that it serves as an important storage source for grain filling (Mundstock \& Thomas, 2005). The abrupt grain filling evolution of TECIRGA $6070 \mathrm{R} R$ can be attributed to indeterminate growth type of this cultivar, since its pods show less uniform grain filling than cultivars with determined growth. These results point to the need to ensure that cultivars with this characteristic receive greater attention as for management practices, until the end of the development cycle, to enable all reserves to be translocated to grains. Soybean 'TECIRGA 6070RR', developed to tolerate longer periods of soil water excess, showed higher total dry matter accumulation than the other cultivars on the market. For grain yield, there was no interaction between cultivar and water availability, and there was no difference, whithin each factor, at both sites. In Santa Maria, productivity ranged from 5,146 to $5,378 \mathrm{~kg} \mathrm{ha}^{-1}$, and in Cachoeirinha, from 4,488 to $4,643 \mathrm{~kg} \mathrm{ha}^{-1}$. These high yields are within the range $(4,300$ and $6,000 \mathrm{~kg}$ $\mathrm{ha}^{-1}$ ) found for soybean cultivation in hydromorphic and nonhydromorphic soils in Rio Grande do Sul (Zanon et al., 2015; Sartori et al., 2016). Moreover, they corroborate the hypothesis that although water deficits during crop cycle have no effect on

Table 1. Soil water content at $10 \mathrm{kPa}\left(\Theta_{10 \mathrm{kPa}}\right)$ and at $1,500 \mathrm{kPa}\left(\Theta_{1500} \mathrm{kPa}\right)$, maximum soil available water capacity $(\mathrm{AWC})$, percentage of sand, silt and clay, total porosity, macro- and microporosity, and bulk density (Ds) of each soil layer, in the municipalities of Cachoeirinha and Santa Maria, both in the state of Rio Grande do Sul, Brazil.

\begin{tabular}{|c|c|c|c|c|c|c|c|c|c|c|c|}
\hline \multirow[t]{2}{*}{ Location } & \multirow{2}{*}{$\begin{array}{c}\text { Layer } \\
(\mathrm{cm})\end{array}$} & \multirow{2}{*}{$\Theta_{10 \mathrm{kPa}}$} & \multirow{2}{*}{$\begin{array}{l}\Theta_{1,500 \mathrm{kPa}} \\
\text { 3)--- }\end{array}$} & \multirow{2}{*}{$\begin{array}{l}\text { AWC } \\
(\mathrm{mm}) \\
\end{array}$} & \multirow{2}{*}{ Sand } & \multirow{2}{*}{$\begin{array}{c}\text { Silt } \\
-\left(\mathrm{g} \mathrm{kg}^{-1}\right) \\
\end{array}$} & \multirow{2}{*}{ Clay } & \multicolumn{3}{|c|}{ Porosity $\left(\mathrm{cm}^{3} \mathrm{~cm}^{-3}\right)$} & \multirow{2}{*}{$\begin{array}{c}\text { Ds } \\
\left(\mathrm{cm}^{3} \mathrm{~cm}^{-3}\right) \\
\end{array}$} \\
\hline & & & & & & & & Total & Macro & Micro & \\
\hline & $0-13$ & 0.373 & 0.095 & 36.2 & 550 & 300 & 150 & 0.425 & 0.338 & 0.087 & 1.603 \\
\hline \multirow[t]{3}{*}{ Cachoeirinha } & $13-20$ & 0.325 & 0.094 & 16.1 & 520 & 320 & 160 & 0.370 & 0.294 & 0.076 & 1.751 \\
\hline & $20-50$ & 0.329 & 0.103 & 67.7 & 550 & 280 & 170 & 0.369 & 0.297 & 0.072 & 1.793 \\
\hline & $0-15$ & 0.310 & 0.163 & 22.2 & 350 & 420 & 220 & 0.402 & 0.081 & 0.321 & 1.597 \\
\hline \multirow[t]{2}{*}{ Santa Maria } & $15-30$ & 0.365 & 0.157 & 31.2 & 350 & 390 & 250 & 0.440 & 0.060 & 0.380 & 1.403 \\
\hline & $30-50$ & 0.369 & 0.200 & 33.8 & 280 & 370 & 350 & 0.493 & 0.106 & 0.386 & 1.261 \\
\hline
\end{tabular}



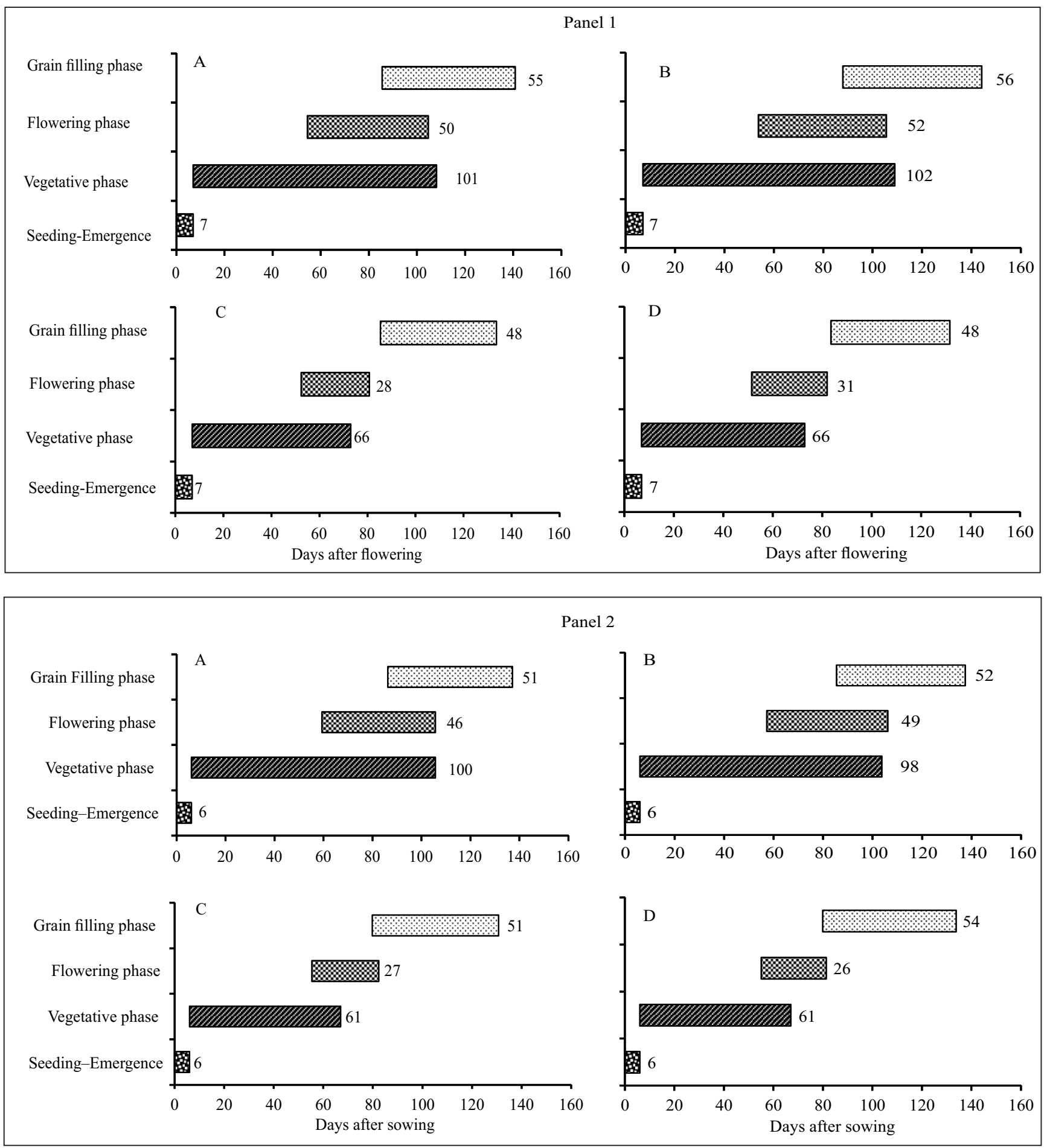

Figure 2. Timing and duration of critical developmental phases of soybean (Glycine max) as a function of days after sowing (DAS), in the municipalities of Cachoeirinha (panel 1) and Santa Maria (panel 2), for the cultivars TECIRGA 6070RR ( $1 \mathrm{~A}, 1 \mathrm{~B}, 2 \mathrm{~A}$, and $2 \mathrm{~B})$ and $\mathrm{A}$ 6411RG $(1 \mathrm{C}, 1 \mathrm{D}, 2 \mathrm{C}$, and $2 \mathrm{D})$, irrigated $(1 \mathrm{~A}, 1 \mathrm{C}, 2 \mathrm{~A}$, and 2 C) or nonirrigated (1 B, 1 D, 2 B, and 2 D), during the 2014/2015 growing season. Vegetative phase, from V0 to $\mathrm{Vn}$; flowering phase, from R1 to the last opened flower; grain filling phase, from first pod with $2 \mathrm{~mm}$ grain to R7, according to Fehr et al. (1971). 
productivity reductions, the productive potential of hydromorphic soils is limited, in comparison to that of nonhydromorphic soils.

The present study was carried out in a single year without severe water deficit; however, water excess and low water deficits were observed for soybean grown in a hydromorphic soil, in the municipality of Cachoeirinha. Therefore, there is a need for further studies aiming to increase soil water availability and, at the same time, to enable fast soil drainage, when rotating soybean with irrigated rice. In this context, soybean crop management in hydromorphic soils should be treated as a higher risk activity, as stresses at an ecophysiological
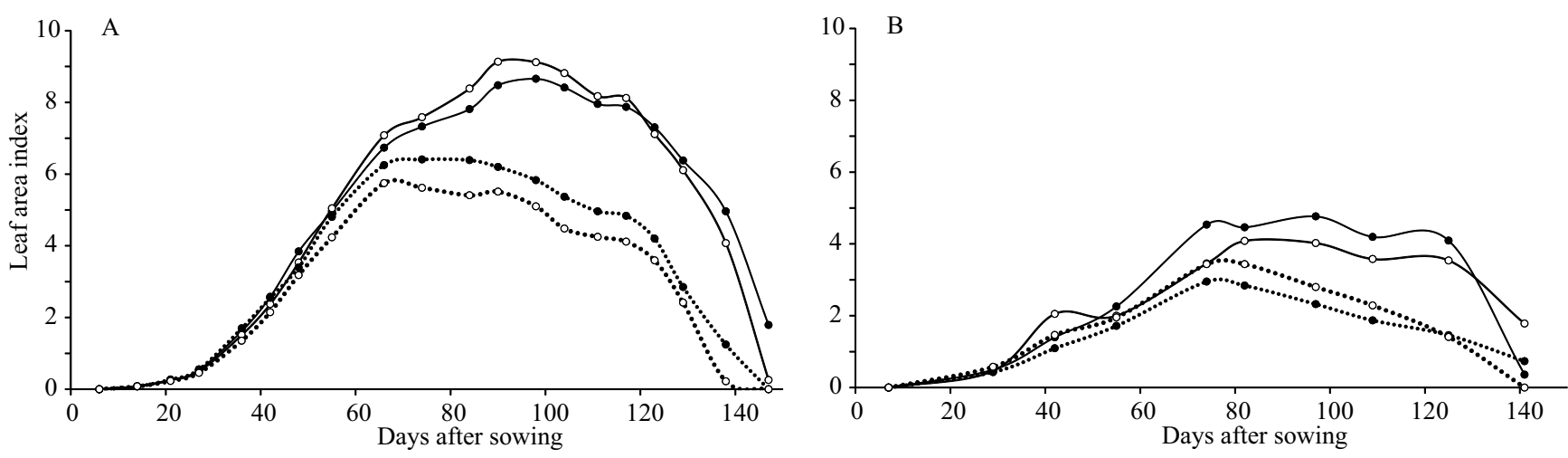

$\rightarrow$ TECIRGA 6070RR irrigated $\quad$ - TECIRGA 6070RR nonirrigated

A $6411 \mathrm{RG}$ irrigated

..*. A 6411RG nonirrigated

Figure 3. Daily dynamics of leaf area index of soybean (Glycine max) cultivars TECIRGA 6070RR and A 6411RG grown under irrigated or nonirrigated conditions as a function of days after sowing (DAS), in the municipalities of Santa Maria (A) and Cachoeirinha (B), both in the state of Rio Grande do Sul, Brazil, during the 2014/2015 growing season.

Table 2. Mean values of photosynthetic rate (A) and stomatal conductance (Gs) in two soybean (Glycine max) cultivars and in two soil water conditions (irrigated and nonirrigated), and average of days with no soil water stress $(\mathrm{ETc}=\mathrm{ETR})$ or with soil water stress (Def., when ETR $>$ ETc) ${ }^{(1)}$.

\begin{tabular}{|c|c|c|c|c|c|c|c|c|}
\hline \multirow[t]{3}{*}{ Cultivar } & \multicolumn{4}{|c|}{ Irrigated } & \multicolumn{4}{|c|}{ Nonirrigated } \\
\hline & \multicolumn{2}{|c|}{ Cachoeirinha } & \multicolumn{2}{|c|}{ Santa Maria } & \multicolumn{2}{|c|}{ Cachoeirinha } & \multicolumn{2}{|c|}{ Santa Maria } \\
\hline & $\begin{array}{c}\mathrm{A} \\
\left(\mu \mathrm{mol} \mathrm{CO} \mathrm{CO}_{2}\right. \\
\left.\mathrm{m}^{-2} \mathrm{~s}^{-1}\right)\end{array}$ & $\begin{array}{c}\text { Gs } \\
\left(\mathrm{mol} \mathrm{H}_{2} \mathrm{O}\right. \\
\left.\mathrm{m}^{-2} \mathrm{~s}^{-1}\right)\end{array}$ & $\begin{array}{c}\mathrm{A} \\
(\mu \mathrm{mol} \mathrm{CO} 2 \\
\left.\mathrm{m}^{-2} \mathrm{~s}^{-1}\right)\end{array}$ & $\begin{array}{c}\text { Gs } \\
\left(\mathrm{mol} \mathrm{H}_{2} \mathrm{O}\right. \\
\left.\mathrm{m}^{-2} \mathrm{~s}^{-1}\right)\end{array}$ & $\begin{array}{c}\mathrm{A} \\
\left(\mu \mathrm{mol} \mathrm{CO} \mathrm{CO}_{2}\right. \\
\left.\mathrm{m}^{-2} \mathrm{~s}^{-1}\right)\end{array}$ & $\begin{array}{c}\mathrm{Gs} \\
\left(\mathrm{mol} \mathrm{H} \mathrm{H}_{2} \mathrm{O}\right. \\
\left.\mathrm{m}^{-2} \mathrm{~s}^{-1}\right)\end{array}$ & $\begin{array}{c}\mathrm{A} \\
\left(\mu \mathrm{mol} \mathrm{CO} \mathrm{CO}_{2}\right. \\
\left.\mathrm{m}^{-2} \mathrm{~s}^{-1}\right)\end{array}$ & $\begin{array}{c}\mathrm{Gs} \\
\left(\mathrm{mol} \mathrm{H}_{2} \mathrm{O}\right. \\
\left.\mathrm{m}^{-2} \mathrm{~s}^{-1}\right)\end{array}$ \\
\hline TECIRGA 6070RR & $16.16 \mathrm{a}$ & $0.28 \mathrm{a}$ & $21.20 \mathrm{a}$ & $0.41 \mathrm{a}$ & $16.95 \mathrm{a}$ & $0.28 \mathrm{a}$ & 19.71a & $0.40 \mathrm{~b}$ \\
\hline A $6411 R G$ & $15.89 \mathrm{a}$ & $0.33 \mathrm{a}$ & $21.96 \mathrm{a}$ & $0.48 \mathrm{a}$ & $15.44 \mathrm{a}$ & $0.27 \mathrm{a}$ & $20.18 \mathrm{a}$ & $0.46 \mathrm{a}$ \\
\hline No stress & $18.29 \mathrm{a}$ & $0.39 \mathrm{a}$ & $22.50 \mathrm{a}$ & $0.46 \mathrm{a}$ & $17.62 \mathrm{a}$ & $0.33 \mathrm{a}$ & $20.86 a$ & $0.47 \mathrm{a}$ \\
\hline Def. & $13.77 \mathrm{~b}$ & $0.22 b$ & $20.66 \mathrm{a}$ & $0.43 \mathrm{a}$ & $14.78 b$ & $0.22 b$ & $19.02 b$ & $0.40 \mathrm{~b}$ \\
\hline Cultivar $\mathrm{x}$ water conditions & ns & ns & ns & ns & ns & ns & ns & ns \\
\hline CV $1(\%)$ & $(26.6)$ & $(22.7)$ & (5.3) & $(17.7)$ & $(19.8)$ & (26.4) & $(8.9)$ & $(8.4)$ \\
\hline CV $2(\%)$ & $(11.5)$ & $(16.8)$ & $(8.9)$ & $(9.0)$ & $(9.6)$ & $(13.1)$ & $(6.5)$ & $(8.5)$ \\
\hline
\end{tabular}

${ }^{(1)}$ Means followed by equal letters, in the columns, do not differ by Tukey's test, at $5 \%$ probability. ns Nonsignificant. CV 1 , coeficiente of variation of factor A; and CV 2, coeficiente of variation of factor B. ETc, crop evapotranspiration; and ETR, reference evapotranspiration. 

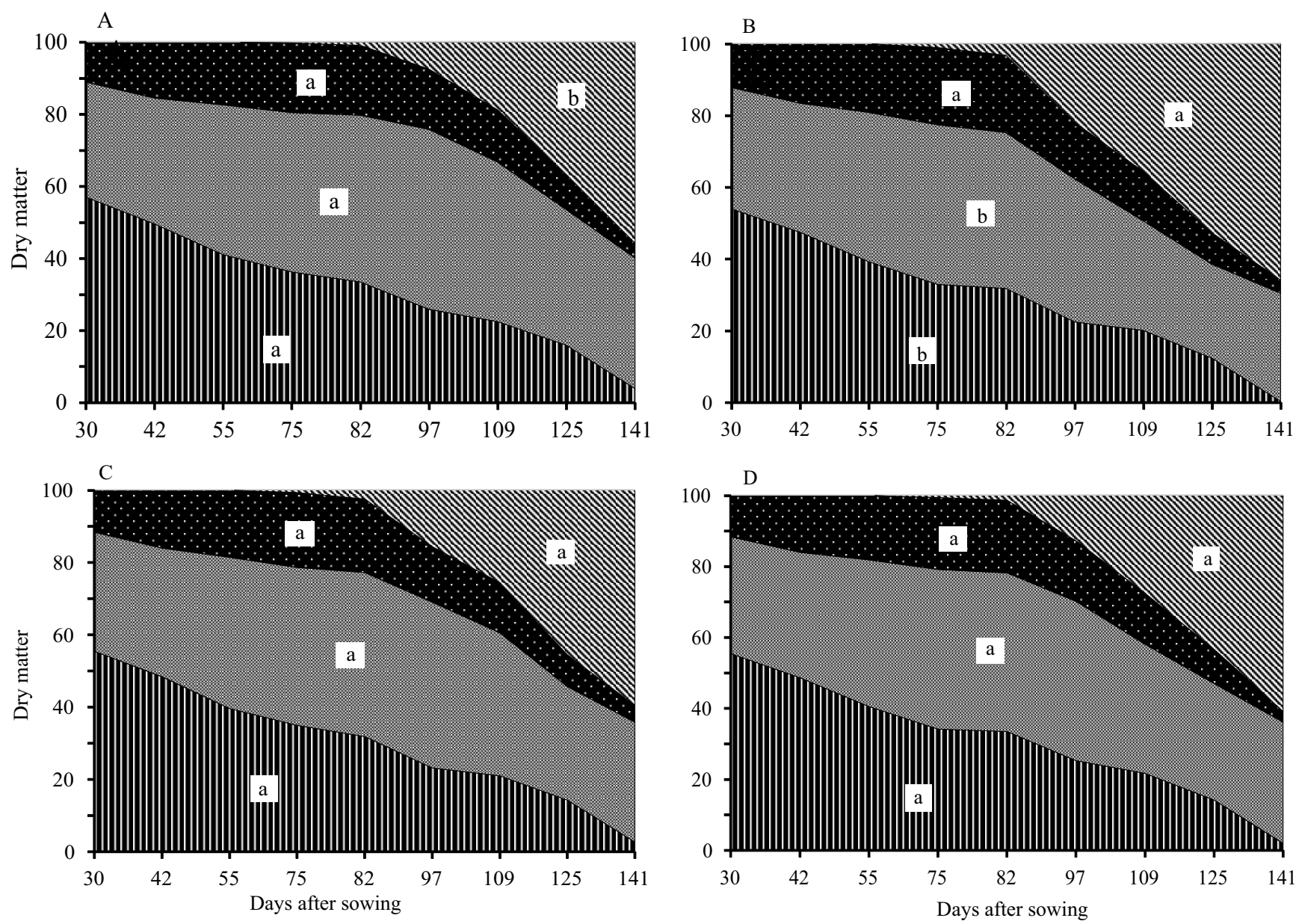

nLeaf $\quad$ Stem Petiole $\$$ Pod and grain

Figure 4. Partitioning of soybean (Glycine max) shoot dry matter for the cultivars TECIRGA 6070RR (A) and A 6411RG (B), and for irrigated (C) and nonirrigated (D) conditions as a function of days after sowing (DAS), in the municipality of Cachoeirinha, in the state of Rio Grande do Sul, Brazil, during the 2014/2015 growing season. Shaded areas followed by equal letters comparing horizontal graphics do not differ by Tukey's test, at 5\% probability.

scale, to which this crop might be exposed during its lifecycle, are most common in this environment than in highlands.

\section{Conclusions}

1. The duration of soybean (Glycine max) development stages and total cycle are similar for plants grown in hydromorphic and nonhydromorphic soils, and it is unaffected by irrigation.

2. The duration of the flowering period is $40 \%$ higher in 'TECIRGA 6070RR', which shows an abrupt grain filling evolution at the end of the cycle, due to its indeterminate growth type.
3. Soybean cultivation in hydromorphic soils exposes plants to water stress, even in years with welldistributed rainfall over the growing season, due to the low water storage capacity of these soils.

\section{Acknowledgments}

To Coordenação de Aperfeiçoamento de Pessoal de Nível Superior (Capes) and to Conselho Nacional de Desenvolvimento Científico e Tecnológico (CNPq), for scholarships granted; and to Instituto Rio Grandense do Arroz (Irga), for allowing the experiments to be carried out at their facilities in the municipality of Cachoeirinha. 


\section{References}

ALLEN, R.G.; PEREIRA, L.S.; RAES, D.; SMITH, M. Crop evapotranspiration (guidelines for computing crop water requirements). Rome: FAO, 1998. 300p. (FAO Irrigation and Drainage Paper, n.56).

BERLATO, M.A.; MATZENAUER, R.; BERGAMASCHI, H. Evapotranspiração máxima da soja e relações com a evapotranspiração calculada pela equação de Penman, evaporação de tanque "classe A" e radiação solar global. Agronomia Sulriograndense, v.22, p.243-259, 1986.

BERNARDES, B.C. Exigências de rotações, soja, feijão miúdo. In: MELHORAMENTOS da rizicultura no Rio Grande do Sul. Porto Alegre: Oficinas Gráficas da Imprensa Oficial, 1946. p.93185.

CARIDE, C.; PIÑEIRO, G; PARUELO, J.M. How does agricultural management modify ecosystem services in the argentine Pampas? The effects on soil C dynamics. Agriculture, Ecosystems and Environment, v.154, p.23-33, 2011. DOI: 10.1016/j.agee.2011.05.031.

CASTILlO, J.; BONILlA, F.; LUCAS, T.; AMARAL, R.; TERRA, J. La integración del cultivo de soja a la rotación arrozpasturas en el este. Arroz, v.15, p.36-39, 2013.

CHEBATAROFF, N.; ZORRILLA, H.; FERREIRA, E.; GAGO, J.; LIMA, R.; MIRABALlES, R.; GONNET, D. Cultivos de alternativa en rotación con arroz. Revista del Plan Agropecuario, v.103 p.50-53, 2002.

CORNELIOUS, B.; CHEN, P.; HOU, A.; SHI, A.; SHANNON, J.G. Yield potential and waterlogging tolerance of selected nearisogenic lines and recombinant inbred lines from two southern soybean populations. Journal of Crop Improvement, v.16, p.97-111, 2006. DOI: 10.1300/J411v16n01_07.

DE BRUIN, J.L.; SINGER, J.W.; PEDERSEN, P.; ROTUNDO, J.L. Soybean photosynthetic rate and carbon fixation at early and late planting dates. Crop Science, v.50, p.2516-2524, 2010. DOI: 10.2135/cropsci2010.02.0107.

FEHR, W.R.; CAVINESS, C.E.; BURMOOD, D.T.; PENNINGTON, J.S. Stage of development descriptions for soybeans, Glycine max (L.) Merrill. Crop Science, v.11, p.929931, 1971. DOI: 10.2135/cropsci1971.0011183X001100060051x.

IRGA. Instituto Rio Grandense do Arroz. Levantamento de área semeada com soja em terras baixas no Rio Grande do Sul. Porto Alegre: Irga, 2016. Available at: <http://www.irga. rs.gov.br/upload/20160819164909soja_safra_2015_2016.pdf $>$. Accessed on: Mar. 132016.

LANGE, C.E.; VEDELAGO, A.; STECKLING, C.; ROVERSI, T. Nova cultivar de soja TECIRGA 6070 RR desenvolvida para o cultivo em solos arrozeiros gaúchos. In: CONGRESSO BRASILEIRO DE ARROZ IRRIGADO, 8., 2013, Santa Maria. Avaliando cenários para a produção sustentável de arroz: anais. Santa Maria: UFSM; Porto Alegre: Sosbai, 2013. p.196199.

MENTGES, M.I.; REICHERT, J.M.; GUBIANI, P.I.; REINERT, D.J.; XAVIER, A. Alterações estruturais e mecânicas de solo de várzea cultivado com arroz irrigado por inundação. Revista
Brasileira de Ciência do Solo, v.37, p.221-231, 2013. DOI: 10.1590/S0100-06832013000100023.

MIYASAKA, S.; MEDINA, J.C. (Ed.). A soja no Brasil. Campinas: ITAL, 1981. 1062p.

MUNDSTOCK, C.M.; THOMAS, A.L. Soja: fatores que afetam o crescimento e o rendimento de grãos. Porto Alegre: Ed. da Universidade Federal do Rio Grande do Sul: Evangraf, 2005. $31 \mathrm{p}$.

ORTIGARA, C.; KOPPE, E.; LUZ, F.B. da; BERTOLLO, A.M.; KAISER, D.R.; SILVA, V.R. da. Uso do solo e propriedades físico-mecânicas de Latossolo Vermelho. Revista Brasileira de Ciência do Solo, v.38, p.619-626, 2014. DOI: 10.1590/S010006832014000200026 .

PEREIRA, C.R. Análise do crescimento e desenvolvimento da cultura de soja sob diferentes condições ambientais. 2002. 282p. Tese (Doutorado) - Universidade Federal de Viçosa, Viçosa.

RICHTER, G.L.; ZANON JÚNIOR, A.; STRECK, N.A.; GUEDES, J.V.C.; KRÄULICH, B.; ROCHA, T.S.M. da; WINCK, J.E.M.; CERA, J.C. Estimativa da área de folhas de cultivares antigas e modernas de soja por método não destrutivo. Bragantia, v.73, p.416-425, 2014. DOI: 10.1590/16784499.0179.

SARTORI, G.M.S.; MARCHESAN, E.; DE DAVID, R.; CARLESSO, R.; PETRY, M.T.; DONATO, G.; CARGNELUTTI FILHO, A.; SILVA, M.F. da. Rendimento de grãos de soja em função de sistemas de plantio e irrigação por superfície em Planossolos. Pesquisa Agropecuária Brasileira, v.50, p.11391149, 2015. DOI: 10.1590/S0100-204X2015001200003.

SARTORI, G.M.S.; MARCHESAN, E.; DE DAVID, R.; DONATO, G.; COELHO, L.L.; AIRES, N.P.; ARAMBURU, B.B. Sistemas de preparo do solo e de semeadura no rendimento de grãos de soja em área de várzea. Ciência Rural, v.46, p.492498, 2016. DOI: 10.1590/0103-8478cr20150676.

SINCLAIR, T.R. Leaf CER from post-flowering to senescence of field-grown soybean cultivars. Crop Science, v.20, p.196-200, 1980. DOI: $10.2135 /$ cropsci1980.0011183X002000020012x.

STRECK, E.V.; KÄMPF, N.; DALMOLIN, R.S.D.; KLAMT, E.; NASCIMENTO, P.C. do; SCHNEIDER, P.; GIASSON, E.; PINTO, L.F.S. Solos do Rio Grande do Sul. 2.ed. rev. e ampl. Porto Alegre: UFRGS: Emater/RS-Ascar, 2008. 126p.

STRECK, N.A. Do we know how plants sense a drying soil? Ciência Rural, v.34, p.581-584, 2004. DOI: 10.1590/S010384782004000200039

THOMAS, A.L.; LANGE, C.E. Soja em solos de várzea do Sul do Brasil. Porto Alegre: Evangraf, 2014. 128p.

THORNTHWAITE, C.W.; MATHER, J.R. The water balance. Centerton: Drexel Institute of Technology, 1955. 104p. (Publications in Climatology, v.8, n.1).

VERNETTI JUNIOR, F. de J.; GOMES, A. da S.; SCHUCH, L.O.B. Sucessão de culturas em solos de várzea implantadas nos sistemas plantio direto e convencional. Revista Brasileira de 
Agrociência, v.15, p.37-42, 2009. DOI: 10.18539/CAST.V15I14.1984 .

ZANON, A.J.; STRECK, N.A.; GRASSINI, P. Climate and management factors influence soybean yield potential in a subtropical environment. Agronomy Journal, v.108, p.14471454, 2016. DOI: 10.2134/agronj2015.0535.
ZANON, A.J.; WINCK, J.E.M.; STRECK, N.A.; ROCHA, T.S.M. da; CERA, J.C.; RICHTER, G.L.; LAGO, I.; SANTOS, P.M. dos; MACIEL, L. da R.; GUEDES, J.V.C; MARCHESAN, E. Desenvolvimento de cultivares de soja em função do grupo de maturação e tipo de crescimento em terras altas e terras baixas. Bragantia, v.74, p.400-411, 2015. DOI: 10.1590/1678-4499.0043.

$\overline{\text { Received on June 12, } 2016 \text { and accepted on November 11, } 2016}$ 